\title{
Corpo de Marfim: Prosápia e Disfarces
}

Miguel Sanches Neto ${ }^{1}$

\section{I - Prosápia}

O livro Corpo de Marfim, de Juarez Poletto, (Livros HDV, 1989) se insere, por um lado, dentro da atual vertente romanesca que trabalha com a reciclagem de temas e enredos, e, por outro, na narrativa de cunho policial. Dizendo apenas isso ficaríamos na superfície deste livro que traz algumas singularidades que ultrapassam o contexto em que se manifestam, problematizando a prática deste gênero.

Começo este pequeno ensaio analisando dois personagens em especial que, dado o papel que representam no corpo da narrativa, possibilitam um melhor entendimento desta. São eles: Rubem e Silviano. Não me interessa, por ora, a procedência destes, mas sim a carga alegórica de que são portadores. Simbolizam as duas espinhas dorsais do romance: a que valoriza a trama policial, buscando suas falhas e verdades e a que valoriza o recôndito, a subjetividade. Valeria a pena lembrar que as posições defendidas e/ou vivenciadas por estes personagens, que não são propriamente antagônicos mas complementares, confluem para o corpo do romance. Valeria ainda dizer que são eles que, dos bastidores, conduzem a primeira parte da narrativa que, graças a esta bipolaridade, cria a tensão entre a originalidade e a apropriação, a verdade e a farsa, o compromisso social e a alienação, etc... O narrador desta primeira parte é uma espécie de joguete nas mãos destes dois personagens/paradigmas.

Essa interferência interna se radicaliza no momento em que se percebe que os personagens em questão não estão apenas no campo do ficcional, mas que são apropriações de seres reais levados à ficção, escritores de renome que representam características bem singulares.

Poletto incorpora a seu romance elementos alheios, isto é, personagens de outras obras e apropria-se não somente das histórias mas também dos autores, pelo menos de seus nomes, transformando-os em personagens de seu relato. O que Poletto faz é ler o próprio no

\footnotetext{
${ }^{1}$ Professor-Associado de Literatura Brasileira na Universidade Estadual de Ponta Grossa (UEPG). Doutor em Letras pela Unicamp. Mestre em Teoria Literária pela Universidade Federal de Santa Catarina - UFSC. Email: msn@interponta.com.br
} 
alheio, ou seja, o que o autor tem a dizer o faz também por meio do que outros autores já o fizeram, num diálogo intertextual. Nesse sentido, o romance funciona como um espaço de confluências de obras e autores os mais diversos. Caberia salientar que tal aproximação está muito bem representada na narrativa: o autor coloca Luís Fernando Veríssimo, Luís Antônio de Assis Brasil, Rubem Fonseca, Silviano Santiago, Zulmira Tavares e Cora Rónai vivendo e/ou convivendo em um edifício, ou próximo deste. O edifício, espaço que por natureza promove a aproximação de vidas díspares, provocando a interferência de umas nas outras. Poderíamos ler aqui a alegoria de uma concepção de romance marcada pela aglomeração de planos e vozes: neste caso o romance funcionaria como um edifício que congrega vozes diferentes, ou seja, como um espaço coletivo. Tal leitura nos coloca em face de plurilinguismo, onde planos se sobrepõem tensionando a narrativa central com histórias alternativas. Um trecho do romance pode avalizar esta afirmação: “Aqui estamos cinco homens atados pela dúvida, presos pelas suposições, acorrentados pelas hipóteses: cinco corpos, cinco verdades” (p. 63).

As verdades são múltiplas, assim como as vozes, e todas clamam pela atenção do leitor.

Poletto concebe o escritor como um 'ladrão', aproximando o seu fazer de um furtar, como se sua escritura não nascesse de si, como podemos inferir do seguinte trecho: "Suei sobre o papel, mas as ideias me cansavam, era duro extraí-las do cérebro, por isso fui alimentá-lo com pensamentos outros” (p. 23).

Lembrando Borges, para quem “organizar uma biblioteca é um modo silencioso de exercer a crítica”, poderíamos dizer que para Poletto um dos modos de escrever ficção é desorganizar uma biblioteca - biblioteca aqui entendida como um conjunto eleito de obras. Corpo de Marfim é uma imbricação de outros no eu. Não me interessa demonstrar o texto para descobrir o quê pertence a quem, isto não tem a mínima importância. Poderíamos dizer que Poletto realiza o romance como uma espécie de 'meeting', onde outros autores (re) contam seus casos, que passam a funcionar como células de um novo texto, adquirindo outras significações sem abandonar totalmente as anteriores. Desta tensão surge a singularidade deste romance polifônico (para usar uma metáfora musical). É que Corpo de Marfim não é apenas a soma de todos os livros envolvidos nele, mas algo novo que não se alcança somente com o haver assimilado esta soma, porque ele está precisamente fora dela. 


\section{II - Disfarces}

Agora, gostaria de comentar um dos elementos da narrativa: o narrador. Na primeira parte há um narrador que, dominado pela influência dos personagens Rubem e Silviano, pluraliza as sendas do romance sem optar por nenhuma. Basicamente, são duas estas vertentes: o memorialismo das crônicas da infância e o desenrolar dos fatos que ele está presenciando. A técnica de intercalar narrativas, misturando as secundárias com as principais, é de grande importância para a sustentação do mistério. O narrador, dando igual relevância para todos os casos, consegue embaralhar o leitor - contra quem ele escreve. O mistério se intensifica porque nunca sabemos quais são os elementos relevantes que nos conduzirão para o desfecho da história. O leitor é sempre mantido à margem da verdade. Para tanto, o narrador o conduz para as periferias do enredo, que são - a meu ver - as crônicas da infância. O narrador é, na verdade, um antinarrador, pois tenta despistar, obscurecer a história. Veja-se um trecho onde ele se entrega (ou tenta confundir ainda mais?): "Não sei se o divertido está em recordá-los ou em torná-los públicos. O fato é que os tenho misturado com tantas impressões e situações outras que se perdem. Talvez seja este mesmo o objetivo deste escrito: confundir, assim como a balbúrdia que nos envolve” (p. 83).

A trama é ainda mais complexa, pois nesta primeira parte da história, contada por este narrador, (há um segundo narrador) há a interferência de vozes de fora. Como é o caso da intromissão do revisor, que tenta alertar e/ou desviar ainda mais o leitor quanto ao caráter dos fatos que estão sendo narrados. E há também a “Nota dos Editores”, no fim da primeira parte, que fornece informações de ordem prática, afirmando a existência de um coautor, dada a morte do autor/narrador do início. Este coautor é que conclui a primeira parte, admitindo que refundiu os originais para que pudessem ser publicados e, inclusive, dando um desfecho à sua maneira.

Para finalizar, já na segunda parte, o revisor com veleidades literárias, estando insatisfeito com o romance que está revisando, resolve descobrir os “verdadeiros” fatos da história, acrescentando-lhe um novo fim (ou apresentando um texto novo?). O caso é que

propõe um final, que pode ser ou não o planejado inicialmente, e isso esclarece e confunde, aumentando as tensões do romance: "Retornei a Curitiba na terça, cheio de informações, 
mas os editores exigiram o texto intacto, sem acréscimos. Entreguei-o frustrado e pensei em escrever meu próprio livro, ou melhor, minha versão (grifo meu) sobre tudo” (p. 120).

Eis um livro composto de versões e não de fatos. Um romance que sabota a leitura, dando pistas erradas, criando expectativas falsas. Um enredo aberto, onde várias pessoas metem o bedelho, acrescentando, alterando e despistando. Um livro coletivo, onde, como no jogo de truco, mentir ou fingir que está mentindo são uma coisa só, não tem a menor importância: a prosápia e os disfarces fazem parte das regras.

Mais do que uma mera leitura, somos desafiados a vencer este jogo de disfarces, a fazer o nosso julgamento.

\section{Referência}

POLETTO, Juarez. Corpo de marfim. Curitiba: Livros HDV, 1989. 